\title{
Triple combination therapy with amlodipine, valsartan, and hydrochlorothiazide vs dual combination therapy with amlodipine and hydrochlorothiazide for stage 2 hypertensive patients
}

\section{Maurizio Destro' \\ Nora Crikelair ${ }^{2}$ \\ Joseph Yen ${ }^{2}$ \\ Robert Glazer ${ }^{2}$}

'Azienda Ospedaliera della Provincia di Pavia, Stradella (PV), Italy; ${ }^{2}$ Novartis Pharmaceuticals Corporation, East Hanover, New Jersey, USA
Correspondence: Maurizio Destro Azienda Ospedaliera della Provincia di Pavia, Ospedale Unificato Broni-Stradella, Stradella (PV), Italy

Tel +390385 52214

Fax +390385 52214

Email maurizio_destro@ospedali.pavia.it
This article was published in the following Dove Press journal:

Vascular Health and Risk Management

2 September 2010

Number of times this article has been viewed

Objective: This post hoc analysis evaluated the efficacy and safety of triple therapy with amlodipine/valsartan+hydrochlorothiazide (Aml/Val+HCTZ) vs dual therapy with Aml+HCTZ in stage 2 hypertensive patients.

Methods: The analysis included patients from an eight-week, multicenter, double-blind study, randomized to Aml/Val 10/160 mg or Aml $10 \mathrm{mg}$ groups, who received add-on HCTZ $12.5 \mathrm{mg}$ at week 4 if mean sitting systolic blood pressure (msSBP) was $>130 \mathrm{mmHg}$.

Results: Of the patients receiving Aml/Val+HCTZ and Aml+HCTZ, 98\% (N=133/136) and $96 \%$ ( $N=200 / 208)$ completed the study, respectively. Baseline characteristics were similar across groups (Caucasians, 80.2\%; diabetics, 14.8\%; age, 58.6 years [28.2\% $\geq 65$ years]; body mass index, $31 \mathrm{~kg} / \mathrm{m}^{2}$; mean sitting blood pressure (msBP), 171.5/95.5 mmHg [18\% msSBP $\geq 180 \mathrm{mmHg}]$ ). Aml/Val+HCTZ provided significantly greater msBP reductions from baseline to week 8 than Aml+HCTZ (30.5/13.8 vs 24.3/8.3 mmHg, $P<0.0001)$. The incremental msBP reduction (week 4 to 8 ) with $\mathrm{HCTZ}$ added to $\mathrm{Aml} / \mathrm{Val}$ was greater than when added to Aml $(6.9 / 3.5$ vs 3.1/1.0 mmHg, $P<0.01)$. Treatments were well tolerated with similar overall incidence of adverse events (Aml/Val+HCTZ: 33.8\%, Aml+HCTZ: 33.2\%).

Conclusion: Aml/Val+HCTZ provided significantly greater BP reductions than Aml+HCTZ in patients with stage 2 hypertension. Aml/Val+HCTZ triple therapy may be a suitable option for patients requiring more than two agents to reach target BP.

Keywords: amlodipine, valsartan, stage 2 hypertension, HCTZ, triple therapy

\section{Introduction}

Hypertension is a major risk factor for cardiovascular events and mortality. ${ }^{1,2}$ Despite this awareness, blood pressure (BP) control rates remain low, varying from $5 \%$ to $33 \%$. $^{3-5}$ Thus, effective treatment strategy and management of hypertension are imperative.

Being a multifactorial disease, management of hypertension often requires multiple drugs. In patients whose BP is $\geq 20 / 10 \mathrm{mmHg}$ above the goal, the use of two antihypertensive agents is recommended as an initial therapy. ${ }^{1}$ Combining drugs with complimentary modes of action is pragmatic, as it is more likely to achieve better BP control and it also attenuates the adverse events (AEs) of the constituent monotherapies. ${ }^{6,7}$ Furthermore, the risk of non-compliance, one of the major reasons for 
failure of antihypertensive therapy, is reduced by $24 \%-26 \%$ with use of single pill combination regimens. ${ }^{8}$

Despite the availability of numerous dual drug combinations, BP largely remains uncontrolled, more so in the elderly, black, diabetic, obese, and severely hypertensive patients. ${ }^{9-11}$ Clinical trials including ALLHAT, ACCOMPLISH, INVEST, and LIFE have reported that $23 \%-52 \%$ patients require three or more antihypertensive agents for BP control and target-level maintenance $(<140 / 90$ or $<130 / 80 \mathrm{mmHg}$ depending on cardiovascular risk)., ${ }^{5,16}$ Thus, a triple drug combination therapy would be a desirable treatment option for hypertension.

In a previously reported study by Destro et al, patients with stage 2 hypertension, initially randomized to a regimen of dual therapy with amlodipine (Aml)/valsartan (Val) had greater reductions in BP than patients randomized to Aml monotherapy after 4 weeks. ${ }^{17}$ In this study, hydrochlorothiazide (HCTZ) was added as a third agent at week 4 if the patients were unable to achieve a target BP level, defined as a mean sitting systolic blood pressure $(\mathrm{msSBP})<130 \mathrm{mmHg}$. In this report, we present results of secondary analyses of this study examining the subgroup of patients who required HCTZ add-on therapy to assess the benefits of the triple combination with Aml/Val+HCTZ compared with Aml+HCTZ dual therapy in patients with stage 2 hypertension.

\section{Patients and methods Study design}

This was a post hoc analysis of an eight-week, multicenter (75 centers in Europe and the United States), randomized, double-blind, parallel-group study. The methods are described in detail by Destro et al. ${ }^{17}$ After a three to seven-day washout period, all eligible patients (stage 2 hypertension [msSBP $\geq 160 \mathrm{mmHg}$ and $<200 \mathrm{mmHg}]$ ) were randomized at baseline (week 0) to receive either Aml/Val 5/160 mg or Aml $5 \mathrm{mg}$ for two weeks. After two weeks, the dose of Aml was force-titrated from $5 \mathrm{mg}$ to $10 \mathrm{mg}$ in both treatment arms. HCTZ $12.5 \mathrm{mg}$ was added to both treatment groups at week 4 (open-label), if the patient had not reached the pre-specified protocol criteria of $\mathrm{msSBP}<130 \mathrm{mmHg}$.

All patients included in this study were aged $\geq 18$ years. Patients were excluded at screening if msSBP was $<140 \mathrm{mmHg}$ while receiving more than three antihypertensive medications, or if msSBP was $\geq 140 \mathrm{mmHg}$ and $<180 \mathrm{mmHg}$ while receiving more than two antihypertensive treatments, or if msSBP was $\geq 180 \mathrm{mmHg}$ while receiving more than one antihypertensive medication. Patients with hepatic or renal impairment, secondary hypertension, clinically significant cerebrovascular and cardiovascular disease, type 1 diabetes, and inadequately controlled type 2 diabetes were also excluded.

\section{Efficacy and safety assessments}

Demographics and baseline characteristics of patients requiring $\mathrm{HCTZ}$ and those not requiring $\mathrm{HCTZ}$ at week 4 were summarized. For the efficacy and safety analyses, only the subgroup of patients that required addition of HCTZ at week 4 were evaluated. The efficacy variables were change in msSBP and mean sitting diastolic blood pressure (msDBP) from baseline to week 8 , week 4 to week 8 , and overall BP control rate $(<140 / 90 \mathrm{mmHg})$ at week 8 . Because HCTZ was to be added if msSBP was $\geq 130 \mathrm{mmHg}$, patients included in the efficacy analyses may have an msSBP $<140 \mathrm{mmHg}$ at week 4 . To eliminate bias in assessing the effect of add-on HCTZ therapy on BP control at week 8, patients with BP $<140 / 90 \mathrm{mmHg}$ at week 4 were excluded from the control rate analysis. Subgroup analyses were also performed according to the severity of hypertension ( $\mathrm{msSBP} \geq 180 \mathrm{mmHg}$ at baseline), diabetic status, age group ( $\geq 65$ years), race (Caucasians and Non-Caucasians), and body mass index $(B M I) \geq 30 \mathrm{~kg} / \mathrm{m}^{2}$.

At each visit, sitting BP were measured three times at two to three-min intervals using an Omron BP monitor (Omron Healthcare, Milton Keynes, UK) in accordance with the British Hypertension Society guidelines. ${ }^{18}$ BP readings were made by the same clinician whenever possible, at drug trough (ie, $24 \pm 3 \mathrm{~h}$ post-dose). Safety assessments for this analysis consisted of a summary of AEs during week 4 to week 8 of treatment.

\section{Statistical analysis}

Data gathered in this post hoc analysis was summarized with respect to demographic, efficacy, and safety variables. All efficacy analyses were conducted for the intent-to-treat population (randomized patients with a baseline and at least one post-baseline efficacy assessment).

Changes in msSBP and msDBP at week 8 were analyzed using analysis of covariance model with treatment and region as factors and baseline BP (week 0 or week 4 depending on analysis) as a covariate. The results were presented as least squares mean difference between the treatment groups with 95\% confidence interval and $P$ value. The proportion of patients achieving BP control was analyzed using a logistic regression model, with treatment as factor and baseline BP as a covariate. Summary statistics were performed for further subgroups by age, gender, BMI, and severe SBP at baseline. 


\section{Results}

\section{Patient demographics and disposition}

Of the patients randomized to Aml/Val $(\mathrm{N}=322)$ and Aml $(\mathrm{N}=324)$ treatment arms, $136(42 \%)$ and $208(64 \%)$, respectively, required add-on HCTZ, of whom 133 (98\%) and $200(96 \%)$ completed the study.

Demographic and baseline characteristics of patients requiring add-on HCTZ and those not requiring add-on HCTZ at week 4 are presented in Table 1. Compared to patients who did not receive add-on HCTZ, a greater percentage of patients requiring add-on HCTZ had diabetes $(6.6 \% \mathrm{vs}$ $14.8 \%)$ and severe hypertension at baseline (13.6\% vs $18.0 \%$ ). The baseline msBP of patients requiring add-on HCTZ (Aml/Val+HCTZ: 171.5/96.4 mmHg, Aml+HCTZ: $171.5 / 95.0 \mathrm{mmHg}$ ) was numerically higher compared with patients who did not require add-on therapy (Aml/Val: 169.3/95.1 mmHg, Aml: 169.8/94.1 mmHg). Within the patients who received add-on HCTZ, demographic and baseline characteristics were comparable between the two treatment groups.

\section{Efficacy}

The msSBP and msDBP of patients with week 4 HCTZ add-on therapy is plotted over time in Figure 1. For each post-baseline (week 0) measurement, patients belonging to Aml/Val+HCTZ triple therapy group achieved higher BP reduction than those in $\mathrm{Aml}+\mathrm{HCTZ}$ dual therapy group, with an msBP of $141.2 / 82.2 \mathrm{mmHg}$ vs $147.7 / 87.0 \mathrm{mmHg}$ at week 8. An additional BP-lowering benefit was observed after the week $4 \mathrm{HCTZ}$ add-on in both treatment groups. However, the incremental reduction from week 4 to week 8 was significantly greater with $\mathrm{HCTZ}$ added to Aml/Val compared with HCTZ added to Aml (6.9/3.5 vs 3.1/1.0 mmHg, $P<0.01$ ) (Table 2).

The overall reduction from baseline to week 8 was also significantly greater in the Aml/Val+HCTZ triple combination compared to Aml+HCTZ therapy (30.5/13.8 vs 24.3/8.3 mmHg, $P<0.0001$ ) (Table 2).

In patients not adequately controlled (BP $>140 / 90 \mathrm{mmHg}$ ) at week 4 on their existing medication, HCTZ $12.5 \mathrm{mg}$ add-on for an additional four weeks facilitated attaining $\mathrm{msBP}<140 / 90 \mathrm{mmHg}$ in a higher proportion of patients previously on Aml/Val (37.7\%) than Aml monotherapy (15.4\%).

\section{Subgroups}

Similarly greater reductions in $\mathrm{msBP}$ with $\mathrm{Aml} / \mathrm{Val}+\mathrm{HCTZ}$ triple therapy were observed in all the subgroups by severity of hypertension, diabetic status, age group, race, and BMI, compared with the reductions with Aml+HCTZ dual therapy (Figures $2 \mathrm{a}$ and $2 \mathrm{~b}$ ).

\section{Safety and tolerability}

Both treatment arms were well tolerated. The overall incidence of AEs was similar between the triple and dual

Table I Baseline and demographic characteristics of patients requiring HCTZ and those not requiring HCTZ at week 4

\begin{tabular}{|c|c|c|c|c|}
\hline \multirow[t]{2}{*}{ Characteristics } & \multicolumn{2}{|c|}{ Patients not requiring HCTZ } & \multicolumn{2}{|c|}{ Patients requiring add-on $\mathrm{HCTZ}$} \\
\hline & Aml/Val $(N=186)$ & $\operatorname{Aml}(\mathbf{N}=1 \mid 6)$ & Aml/Val+HCTZ $(\mathrm{N}=136)$ & Aml+HCTZ $(N=208)$ \\
\hline Age \pm SD (years) & $57.5 \pm 10.6$ & $57.3 \pm 10.8$ & $58.8 \pm 9.8$ & $58.5 \pm 10.2$ \\
\hline \multicolumn{5}{|l|}{ Age category, n (\%) } \\
\hline$<65$ years & I 37 (73.7) & $85(73.3)$ & $98(72.1)$ & I49 (7I.6) \\
\hline$\geq 65$ years & $49(26.3)$ & 31 (26.7) & $38(27.9)$ & $59(28.4)$ \\
\hline \multicolumn{5}{|l|}{ Gender, n (\%) } \\
\hline Male & $94(50.5)$ & $51(44.0)$ & $71(52.2)$ & $108(51.9)$ \\
\hline \multicolumn{5}{|l|}{ Race, n (\%) } \\
\hline Caucasians & $159(85.5)$ & $93(80.2)$ & $102(75.0)$ & $174(83.7)$ \\
\hline Blacks & $6(3.2)$ & $2(1.7)$ & $15(11.0)$ & $10(4.8)$ \\
\hline Others & $21(11.3)$ & $21(18.1)$ & $19(13.9)$ & $24(11.6)$ \\
\hline $\mathrm{msSBP} \pm \mathrm{SD}, \mathrm{mmHg}$ & $169.3 \pm 8.6$ & $169.8 \pm 9.1$ & $17 \mid .5 \pm 9.2$ & $|7| .5 \pm 8.1$ \\
\hline $\mathrm{msDBP} \pm \mathrm{SD}, \mathrm{mmHg}$ & $95.1 \pm 9.5$ & $94.1 \pm 10.9$ & $96.4 \pm 10.4$ & $95.0 \pm 10.2$ \\
\hline $\begin{array}{l}\text { Hypertension severity } \\
\text { at baseline, } \mathrm{n}(\%)\end{array}$ & $22(11.8)$ & $19(16.4)$ & $25(18.4)$ & $37(17.8)$ \\
\hline \multicolumn{5}{|l|}{$\geq 180 \mathrm{mmHg}$} \\
\hline Diabetes; n (\%) & $13(7.0)$ & $7(6.0)$ & $22(16.2)$ & 29 (13.9) \\
\hline BMI, Mean \pm SD & $28.9 \pm 4.9$ & $29.7 \pm 5.9$ & $31.1 \pm 5.9$ & $30.7 \pm 5.6$ \\
\hline
\end{tabular}

Abbreviations: Aml/Val+HCTZ, amlodipine/valsartan+hydrochlorothiazide; Aml+HCTZ, amlodipine+hydrocholorothiazide; msSBP, mean sitting systolic blood pressure; msDBP, mean sitting diastolic blood pressure; BMI, body mass index; SD, standard deviation. 


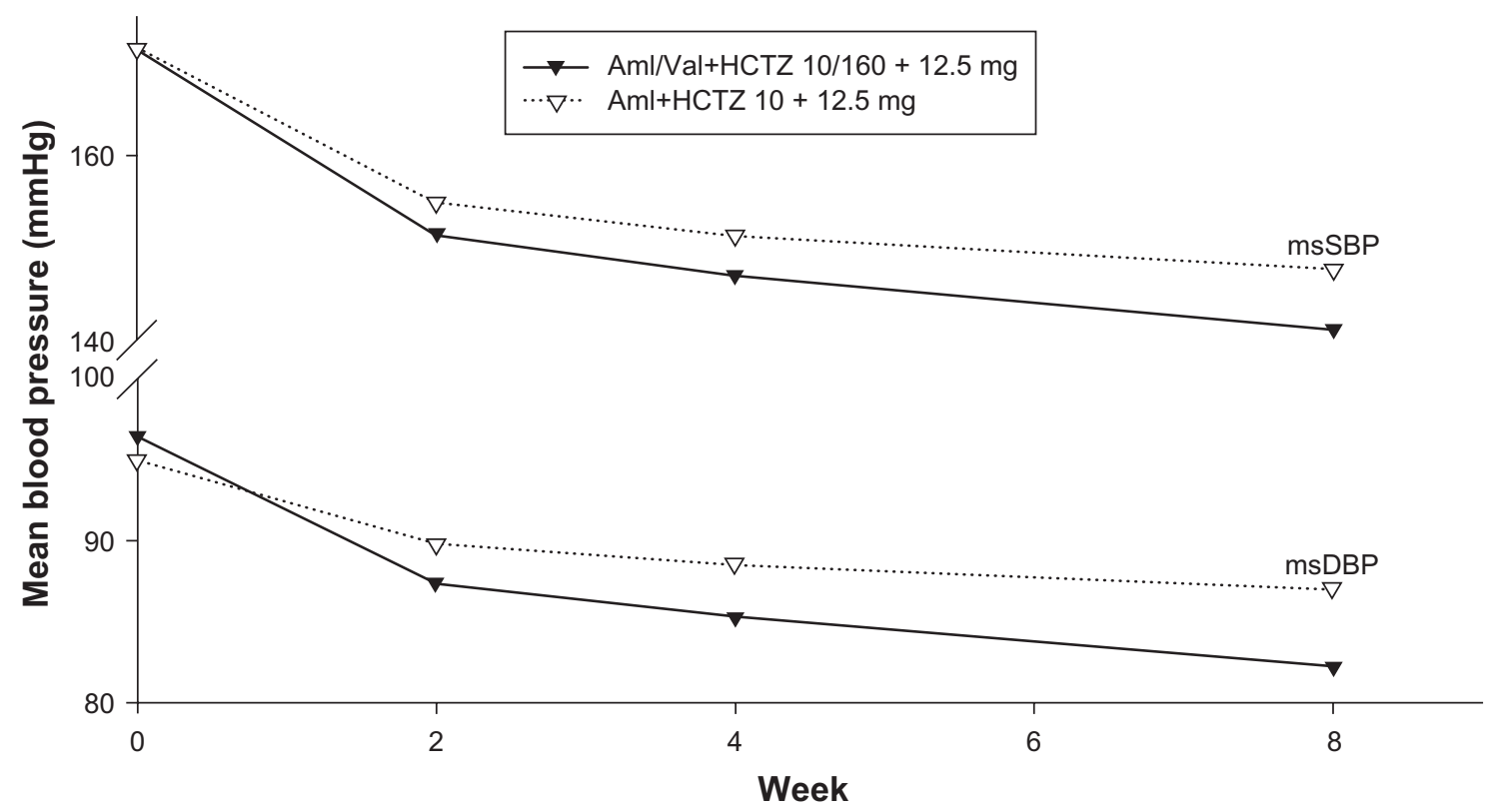

Figure I Mean msSBP and msDBP at each time point.

Abbreviations: msSBP, mean sitting systolic blood pressure; msDBP, mean sitting diastolic blood pressure.

therapies (Table 3). Peripheral edema was the most frequently reported $\mathrm{AE}$, which occurred at a slightly lower frequency in the presence of Val (Aml/Val+HCTZ: $\mathrm{n}=19,14.0 \%$; Aml+HCTZ: $\mathrm{n}=37,17.8 \%$ ).

Amongst patients who received HCTZ add-on at week 4, $1.7 \%(n=6)$ of patients discontinued the study prematurely (Aml/Val+HCTZ; 1.5\% [n = 2], Aml+HCTZ: 1.9\% [n=4]) due to AEs. There were no deaths during the entire course of the study. Serious AEs were also not reported in any treatment group from week 4 to week 8 .

\section{Discussion}

Current hypertension treatment guidelines state that dual combination therapy be considered as initial therapy in patients with $\mathrm{msBP} \geq 20 / 10 \mathrm{mmHg}$ above goal. ${ }^{1,2}$ Furthermore, recent outcome trials suggest that the percentage of patients requiring three or more antihypertensive drugs to achieve BP control can range from $23 \%-52 \%$ depending on the trial. ${ }^{5,14-16}$
In this study, patients with stage 2 hypertension were randomized to initiate therapy with either dual Aml/Val therapy or Aml monotherapy with the addition of HCTZ to either regimen if BP remained uncontrolled. Triple therapy with Aml/Val+HCTZ 10/160/12.5 mg provided clinically and statistically significant additional BP reductions compared with the dual therapy with Aml+HCTZ 10/12.5 mg $(P<0.0001)$. Similarly, Aml/Val+HCTZ triple therapy produced greater BP reductions compared with Aml+HCTZ dual therapy in diverse patient populations, including patients regardless of age, diabetic status, BMI, or race. These results are consistent with those reported by Calhoun et al wherein triple therapy with Aml/Val/HCTZ at a dose of 10/320/25 mg was shown to have superior efficacy compared with Aml/ Val 10/320 mg, Val/HCTZ 320/25 mg, and Aml/HCTZ $10 / 25 \mathrm{mg}$ dual therapies in a parallel-design trial, where patients were randomized to the four treatment groups. ${ }^{19}$ The patients on triple therapy achieved a mean SBP reduction of

Table 2 LSM difference in msSBP/DBP (intent-to-treat population)

\begin{tabular}{|c|c|c|c|c|c|}
\hline & \multirow[t]{2}{*}{$\mathbf{N}$} & \multicolumn{2}{|l|}{ msSBP } & \multicolumn{2}{|l|}{ msDBP } \\
\hline & & LSM change (SEM) & Difference $(95 \% \mathrm{Cl})$ & LSM change (SEM) & Difference $(95 \% \mathrm{Cl})$ \\
\hline \multicolumn{6}{|c|}{ From baseline to week 8} \\
\hline $\mathrm{Aml} / \mathrm{Val}+\mathrm{HCTZ}$ & 133 & $-30.5(1.1)$ & $-6.1(-8.6,-3.6)$ & $-13.8(0.7)$ & $-5.5(-7.1,-3.9)$ \\
\hline $\mathrm{Aml}+\mathrm{HCTZ}$ & 206 & $-24.3(0.9)$ & $P<0.0001$ & $-8.3(0.6)$ & $P<0.0001$ \\
\hline \multicolumn{6}{|c|}{ From week 4 to week 8} \\
\hline $\mathrm{Aml} / \mathrm{Val}+\mathrm{HCTZ}$ & 133 & $-6.9(0.9)$ & $-3.8(-6.1,-1.5)$ & $-3.5(0.6)$ & $-2.6(-3.9,-1.1)$ \\
\hline $\mathrm{Aml}+\mathrm{HCTZ}$ & 206 & $-3.1(0.8)$ & $P=0.0012$ & $-1.0(0.5)$ & $P=0.0004$ \\
\hline
\end{tabular}

Abbreviations: LSM, least squares mean; MSSBP, mean sitting systolic blood pressure; MSDBP, mean sitting diastolic blood pressure; Aml/Val+HCTZ, amlodipine/ valsartan+hydrochlorothiazide; Aml+HCTZ, amlodipine+hydrocholorothiazide; SEM, standard error of mean. 

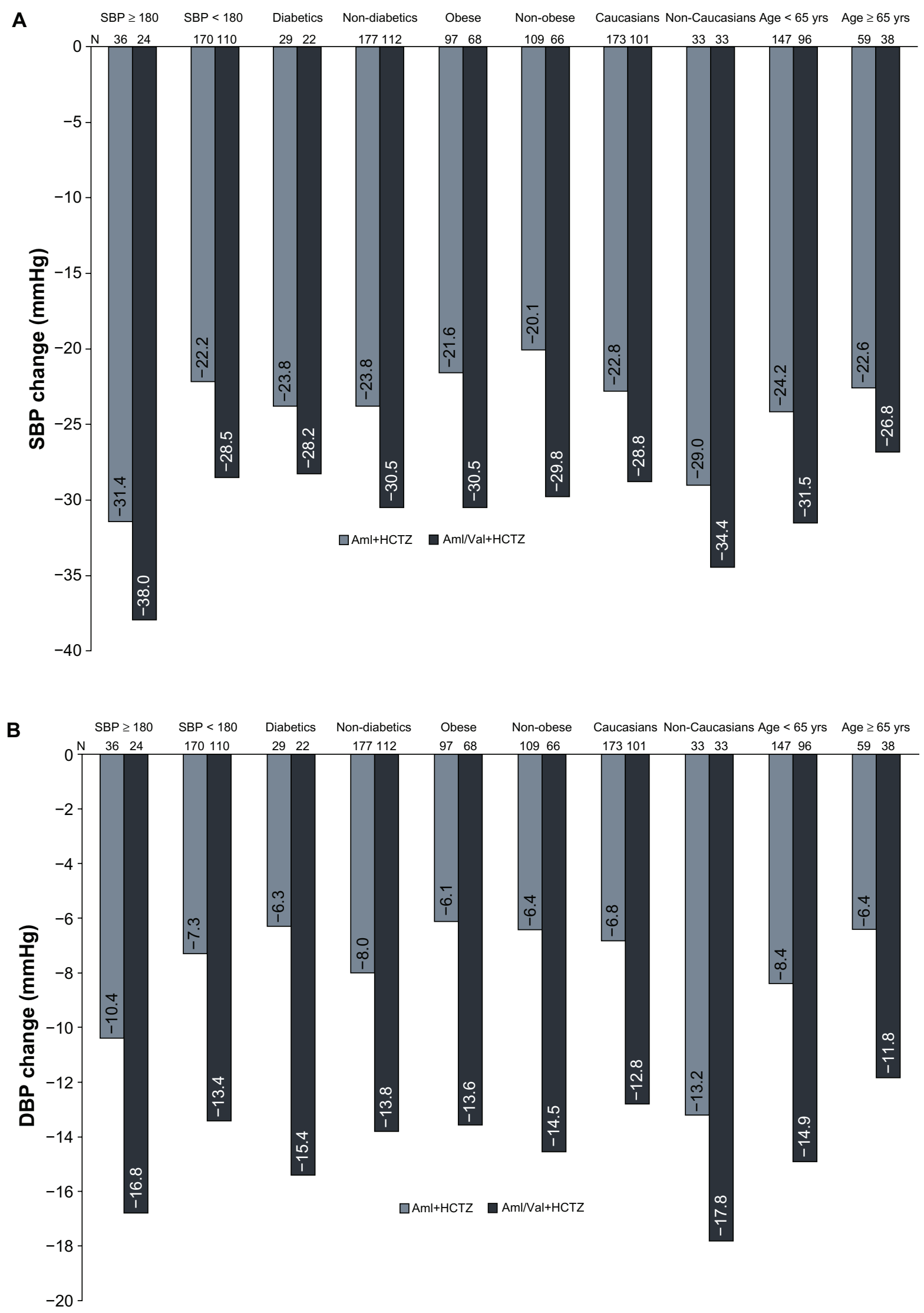

Figure 2 Mean change from baseline to week 8 in $\operatorname{msSBP}(\mathbf{A})$ and $\mathrm{msDBP}(\mathbf{B})$ in subgroups.

Abbreviations: msSBP, mean sitting systolic blood pressure; msDBP, mean sitting diastolic blood pressure; Aml/Val+HCTZ, amlodipine/valsartan+hydrochlorothiazide; Aml+HCTZ, amlodipine+hydrocholorothiazide. 
Table 3 Frequent adverse events (AEs) $\geq 1 \%$ (safety population) in either treatment group

\begin{tabular}{lll}
\hline Event & Aml/Val+HCTZ & Aml+HCTZ \\
& $\mathbf{N}=\mathbf{I 3 6}$ & $\mathbf{N}=\mathbf{2 0 8}$ \\
\hline AEs; n (\%) & $46(33.8)$ & $69(33.2)$ \\
Edema peripheral & $19(14.0)$ & $37(17.8)$ \\
Nasopharyngitis & $4(2.9)$ & $2(1.0)$ \\
Headache & $2(1.5)$ & $5(2.4)$ \\
Dizziness & $2(1.5)$ & $1(0.5)$ \\
Syncope & $2(1.5)$ & $0(0.0)$ \\
Cough & $1(0.7)$ & $4(1.9)$ \\
Diarrhea & $1(0.7)$ & $3(1.4)$ \\
Viral infection & $\mathrm{I}(0.7)$ & $2(1.0)$ \\
Paresthesia & $0(0.0)$ & $2(1.0)$ \\
Joint swelling & $\mathrm{I}(0.7)$ & $2(1.0)$ \\
Dyspepsia & $0(0.0)$ & $3(1.4)$ \\
Flushing & $0(0.0)$ & $3(1.4)$ \\
Upper respiratory tract infection & $0(0.0)$ & $2(1.0)$ \\
Urinary tract infection & $0(0.0)$ & $3(1.4)$ \\
Hypokalemia & $0(0.0)$ & $2(1.0)$ \\
Arthralgia & $0(0.0)$ & $2(1.0)$ \\
Neck pain & $0(0.0)$ & $2(1.0)$ \\
\hline
\end{tabular}

Abbreviations: Aml/Val+HCTZ, amlodipine/valsartan+hydrochlorothiazide; Aml+HCTZ, amlodipine+hydrocholorothiazide.

$40-50 \mathrm{mmHg}$, which was clinically and statistically greater than that with the dual component therapies. ${ }^{19}$ In the present study, a sequential antihypertensive treatment approach dependent on BP level achieved was followed, enabling the assessment of the efficacy and safety of adding a third agent in those patients initiated on dual therapy.

Hypertension is a multifactorial disease and the results of this study confirm that combining therapies with different mechanisms of action can additively reduce BP. Both Aml and Val are vasodilators that work through different mechanisms. Aml blocks calcium channels in vascular smooth muscle and Val blocks the binding of angiotensin II to the angiotensin type 1 receptor. The antihypertensive efficacy of calcium channel blockers (CCBs), however, is reduced by the associated activation of the renin-angiotensin system (RAS) and the sympathetic nervous system..$^{20}$ Coadministration of an angiotensin receptor blocker (ARB) can effectively prevent such responses.

In this study, the response to HCTZ was dependent on the initial treatment, ie, Aml/Val vs Aml. The benefit of adding HCTZ was greater in patients treated with Val. This may be explained by the fact that diuretics decrease intravascular volume, activating RAS resulting in a diminished antihypertensive response. This counter-regulatory effect is prevented in the presence of an ARB. In previous studies, Val and HCTZ in combination have demonstrated additional BP lowering effects compared with each of the component monotherapies..$^{21,22}$ While diminished efficacy of CCBs has been reported with concomitant diuretic therapy, other controlled studies have reported additional antihypertensive efficacy with a CCB and diuretic combination. ${ }^{23,24}$

Adding HCTZ to Aml/Val was not only effective in lowering BP, but was also well tolerated. Treatment discontinuations and the incidence of AEs were low with triple therapy and no difference was observed compared with dual therapy. The most frequently reported $\mathrm{AE}$ was peripheral edema, which appeared to be attenuated in the presence of Val.

Therapies combining drugs with complimentary mechanisms of action have also been recommended because they may attenuate certain AEs like the peripheral edema associated with CCBs and the hypokalemia associated with thiazide diuretics. ${ }^{25,26}$ For example, Val has previously been reported to reduce the incidence of hypokalemia associated with HCTZ and the peripheral edema associated with Aml. ${ }^{21,27}$ Moreover, it has been suggested that combining different drugs in a single pill may lead to better compliance and hence better BP control. ${ }^{28,29}$

This study provides relevant information as it follows the clinical practice of prescribing a third antihypertensive agent in a step-wise manner to initial dual therapy depending on BP levels of the patient. The present analyses, however, have certain limitations: 1) this was a post hoc analysis of a study not designed to evaluate the efficacy of triple therapy vs dual therapy; 2) patients were not randomized to receive Aml/Val/HCTZ and Aml/HCTZ; and 3) the duration of the treatment with triple therapy was four weeks.

In conclusion, triple combination therapy with $\mathrm{Aml} / \mathrm{Val} /$ HCTZ provides significantly greater BP reductions and is well tolerated compared with Aml/HCTZ dual therapy in stage 2 hypertension and can provide additional benefits in patients who require more than two agents to reach their target BP.

\section{Acknowledgments/disclosure}

$M$ Destro has received research support as a study investigator from Novartis Pharma AG, Basel, Switzerland, and has been a speaker at scientific meetings organized by Novartis. M Destro has received consulting and lecture fees and research grants from Boehringer Ingelheim, AstraZeneca, Servier, Menarini IFR, Schering-Plough, Guidotti, Pfizer, Knoll, Bayer, Chiesi, Daiichi-Sankyo, Merck Sharpe \& Dohme; Malesci, and Errekappa. N Crikelair, J Yen, and R Glazer are employees of Novartis Pharmaceuticals Corporation, East Hanover, New Jersey, USA. This study was supported by a grant from Novartis Pharma AG, Basel, Switzerland.

The authors thank Drs Shivali Arora, Ashish Agarwal, and Ramya Rajagopal (Novartis, India) for writing and editorial assistance on this manuscript. 


\section{References}

1. Chobanian AV, Bakris GL, Black HR, et al. The Seventh Report of the Joint National Committee on Prevention, Detection, Evaluation, and Treatment of High Blood Pressure: the JNC 7 report. JAMA. 2003;289(19):2560-2572.

2. Mancia G, De Backer G, Dominiczak A, et al. ESH-ESC Practice Guidelines for the Management of Arterial Hypertension: ESH-ESC Task Force on the Management of Arterial Hypertension. J Hypertens. 2007;25(9):1751-1762.

3. Ong KL, Cheung BM, Man YB, Lau CP, Lam KS. Prevalence, awareness, treatment, and control of hypertension among United States adults 1999-2004. Hypertension. 2007;49(1):69-75.

4. Wolf-Maier K, Cooper RS, Kramer H, et al. Hypertension treatment and control in five European countries, Canada, and the United States. Hypertension. 2004;43(1):10-17.

5. Jamerson K, Weber MA, Bakris GL, et al. Benazepril plus amlodipine or hydrochlorothiazide for hypertension in high-risk patients. $N \mathrm{Engl}$ J Med. 2008;359(23):2417-2428.

6. Sica DA. Current concepts of pharmacotherapy in hypertension - fixed dose combination antihypertensive therapy: is this the future? J Clin Hypertens (Greenwich). 2000;2(1):46-53.

7. Sica DA. Rationale for fixed-dose combinations in the treatment of hypertension: the cycle repeats. Drugs. 2002;62(3):443-462.

8. Bangalore S, Kamalakkannan G, Parkar S, Messerli FH. Fixed-dose combinations improve medication compliance: a meta-analysis. Am J Med. 2007;120(8):713-719.

9. UK Prospective Diabetes Study Group. Tight blood pressure control and risk of macrovascular and microvascular complications in type 2 diabetes: UKPDS 38. BMJ. 1998;317(7160):703-713.

10. Mancia G, Brown M, Castaigne A, et al. Outcomes with nifedipine GITS or Co-amilozide in hypertensive diabetics and nondiabetics in Intervention as a Goal in Hypertension (INSIGHT). Hypertension. 2003;41(3):431-436.

11. Smith TR, Philipp T, Vaisse B, et al. Amlodipine and valsartan combined and as monotherapy in stage 2, elderly, and black hypertensive patients: subgroup analyses of 2 randomized, placebo-controlled studies. J Clin Hypertens (Greenwich). 2007;9(5):355-364.

12. Devereux RB, de Faire U, Fyhrquist F, et al. Blood pressure reduction and antihypertensive medication use in the losartan intervention for endpoint reduction in hypertension (LIFE) study in patients with hypertension and left ventricular hypertrophy. Curr Med Res Opin. 2007;23(2):259-270

13. Bangalore S, Messerli FH, Cohen JD, et al. Verapamil-sustained release-based treatment strategy is equivalent to atenolol-based treatment strategy at reducing cardiovascular events in patients with prior myocardial infarction: an International Verapamil SR-Trandolapril (INVEST) substudy. Am Heart J. 2008;156(2):241-247.

14. Cushman WC, Ford CE, Cutler JA, et al. Success and predictors of blood pressure control in diverse North American settings: the antihypertensive and lipid-lowering treatment to prevent heart attack trial (ALLHAT). J Clin Hypertens (Greenwich). 2002;4(6):393-404.

15. Wright JT Jr, Bakris G, Greene T, et al. Effect of blood pressure lowering and antihypertensive drug class on progression of hypertensive kidney disease: results from the AASK trial. JAMA. 2002;288(19): 2421-2431.
16. Pepine CJ, Handberg EM, Cooper-DeHoff RM, et al. A calcium antagonist vs a non-calcium antagonist hypertension treatment strategy for patients with coronary artery disease. The International VerapamilTrandolapril Study (INVEST): a randomized controlled trial. JAMA. 2003;290(21):2805-2816.

17. Destro M, Luckow A, Samson M, Kandra A, Brunel P. Efficacy and safety of amlodipine/valsartan compared with amlodipine monotherapy in patients with stage 2 hypertension: a randomized, double-blind, multicenter study: the EX-EFFeCTS Study. J Am Soc Hypertens. 2008;2(3):294-302.

18. Williams B, Poulter NR, Brown MJ, et al. Guidelines for management of hypertension: report of the fourth working party of the British Hypertension Society, 2004-BHS IV. J Hum Hypertens. 2004;18(3):139-185.

19. Calhoun DA, Lacourciere Y, Chiang YT, Glazer RD. Triple antihypertensive therapy with amlodipine, valsartan, and hydrochlorothiazide: a randomized clinical trial. Hypertension. 2009;54(1):32-39.

20. Kjeldsen SE, Aksnes TA, de la Sierra A, Ruilope L. Amlodipine and valsartan: calcium channel blockers/angiotensin II receptor blockers combination for hypertension. Therapy. 2007;4(1):31-40.

21. Pool JL, Glazer R, Weinberger M, Alvarado R, Huang J, Graff A Comparison of valsartan/hydrochlorothiazide combination therapy at doses up to $320 / 25 \mathrm{mg}$ versus monotherapy: a double-blind, placebocontrolled study followed by long-term combination therapy in hypertensive adults. Clin Ther. 2007;29(1):61-73.

22. Tuomilehto J, Tykarski A, Baumgart P, Reimund B, Le Breton S, Ferber P. Combination therapy with valsartan/hydrochlorothiazide at doses up to $320 / 25 \mathrm{mg}$ improves blood pressure levels in patients with hypertension inadequately controlled by valsartan $320 \mathrm{mg}$ monotherapy. Blood Press Suppl. 2008;1:15-23.

23. Magagna A, Abdel-Haq B, Pedrinelli R, Salvetti A. Does chlorthalidone increase the hypotensive effect of nifedipine? J Hypertens. 1986;4(Suppl 5):S519-S521.

24. Stergiou GS, Malakos JS, Achimastos AD, Mountokalakis TD. Additive hypotensive effect of a dihydropyridine calcium antagonist to that produced by a thiazide diuretic: a double-blind placebo-controlled crossover trial with ambulatory blood pressure monitoring. J Cardiovasc Pharmacol. 1997;29(3):412-416.

25. Epstein BJ, Roberts ME. Managing peripheral edema in patients with arterial hypertension. Am J Ther. 2009;16(6):543-553.

26. Kjeldsen SE, Os I, Hoieggen A, Beckey K, Gleim GW, Oparil S. Fixed-dose combinations in the management of hypertension: defining the place of angiotensin receptor antagonists and hydrochlorothiazide. Am J Cardiovasc Drugs. 2005;5(1):17-22.

27. Philipp T, Smith TR, Glazer R, et al. Two multicenter, 8-week, randomized, double-blind, placebo-controlled, parallel-group studies evaluating the efficacy and tolerability of amlodipine and valsartan in combination and as monotherapy in adult patients with mild to moderate essential hypertension. Clin Ther. 2007;29(4):563-580.

28. Gerbino PP, Shoheiber O. Adherence patterns among patients treated with fixed-dose combination versus separate antihypertensive agents. Am J Health Syst Pharm. 2007;64(12):1279-1283.

29. Bramley TJ, Gerbino PP, Nightengale BS, Frech-Tamas F. Relationship of blood pressure control to adherence with antihypertensive monotherapy in 13 managed care organizations. J Manag Care Pharm. 2006;12(3):239-245.
Vascular Health and Risk Management

\section{Publish your work in this journal}

Vascular Health and Risk Management is an international, peerreviewed journal of therapeutics and risk management, focusing on concise rapid reporting of clinical studies on the processes involved in the maintenance of vascular health; the monitoring, prevention and treatment of vascular disease and its sequelae; and the involvement of

\section{Dovepress}

metabolic disorders, particularly diabetes. This journal is indexed on PubMed Central and MedLine. The manuscript management system is completely online and includes a very quick and fair peer-review system, which is all easy to use. Visit http://www.dovepress.com/ testimonials.php to read real quotes from published authors. 